\title{
IMPLEMENTASI KEWAJIBAN PEMBINAAN TERHADAP PIDANA ANAK DI LEMBAGA PEMBINAAN KHUSUS ANAK PEKANBARU BERDASARKAN UNDANG-UNDANG REPUBLIK INDONESIA NOMOR 11 TAHUN 2012 \\ Erpis Candra ${ }^{1}$, Eddy Asnawi ${ }^{2}$, Bagio Kadaryanto ${ }^{3}$
}

${ }^{1}$ Magister Ilmu Hukum Universitas Lancang Kuning, email: erpis.candra.baserah20@gmail.com 2Magister Ilmu Hukum Universitas Lancang Kuning ${ }^{3}$ Magister Ilmu Hukum Universitas Lancang Kuning

\section{ABSTRAK}

Di dalam Undang-Undang Republik Indonesia Nomor 11 Tahun 2012 Tentang Sistem Peradilan Pidana Anak 85 ayat 2 dan ayat 3 mengatakan bahwa wajib menyelenggarakan pembinaan terhadap anak, baik pembinaan pendidikan, pembinaan keterampilan, dan pembinaan kepribadiaan, namun Pada kenyataannya kewajiban pembinaan di LPKA ini belum berjalan maksimal, terutama pada pembinaan keterampilan dan pembinaan pendidikan. Dalam pembinaan pendidikan di LPKA adalah pendidikan non formal, mencakup kegiatan Paket A untuk sekolah dasar (SD), Paket B untuk sekolah menegah pertama (SMP), dan paket $C$ untuk sekolah menegah atas (SMA). Metode yang dipergunakan adalah penelitian hukum sosiologis. Sumber data terdiri atas data hukum primer, data hukum sekunder, dan data hukum tertier. Dalam penelitian ini data dianalisis secara kualitatif dan dalam menarik kesimpulannya dengan berpikir deduktif.Berdasarkan hasil penelitian diketahui bahwa Implementasi Kewajiban Pembinaan Terhadap Pidana Anak Di Lembaga Pembinaan Khusus Anak Pekanbaru BerdasarkanUndangUndang Republik IndonesiaNomor 11 Tahun 2012 Tentang Sistem Peradilan Pidana Anak bahwa pembinaan anak pidana harus memiliki program yang harus dapat memanusiakan anak, mengasuh, membina, membimbing anak pidana. Pembinaan anak pidana harus berorientasi pada nilai kemasyarakatan menurut penulis sesuai dengan penyelenggaraan perlindungan anak. Akibat Hukum Implementasi Kewajiban Pembinaan Terhadap Pidana Anak Di Lembaga Pembinaan Khusus Anak Pekanbaru BerdasarkanUndang-Undang Republik IndonesiaNomor 11 Tahun 2012 Tentang Sistem Peradilan Pidana Anak bahwa perlakuan sistem terhadap ramah akan anak di aplikasikan seperti pendampingan, pengenalan terhadap diri sendiri dan lingkungannya, program berupa pembinaan, dan pengasuhan terhadap pemasyarakatan hingga mempersiapkan ke reintegrasi sosial anak. pengasuhan pemasyarakatan dapat dilakukan pada saat anak mulai ditempatkan di lembaga Pembinaan Khusus Anak (LPKA).
\end{abstract}

\section{ARTICLE INFO}

\section{Kata Kunci:}

pembinaan khusus;

peradilan anak;

lembaga Pembinaan

Khusus Anak

\section{Cite this paper:}

Erpis Candra, E. A. B. K., 2020. Implementasi

Kewajiban Pembinaan

Terhadap Pidana Anak

Di Lembaga Pembinaan

Khusus Anak

Pekanbaru

Berdasarkan Undang-

Undang Republik

Indonesia Nomor 11

Tahun 2012. Widya

Yuridika: Jurnal Hukum,

$3(2)$. 


\section{PENDAHULUAN}

Lembaga Pembinaan Khusus Anak (LPKA) adalah lembaga atau tempat anak menjalani masa pidananya. LPKA berkewajiban untuk menyelenggarakan pendidikan, pelatihan keterampilan, pembinaan, dan pemenuhan lain dari anak sesuai dengan ketentuan perundang-undangan. Hal ini mengingat anak yang dijatuhi pidana berhak memperoleh pembinaan, pembimbingan, pengawasan, pendampingan, pendidikan, dan pelatihan serta hak lain sesuai dengan ketentuan peraturan perundang-undangan. ${ }^{1}$ Sehingga dapat didefinisikan Lembaga Pembinaan khusus Anak adalah suatu tempat anak menjalani masa pidananya yang tetap memperhatikan hak-hak anak seperti mendapatkan pembimbingan dan pembinaan bagi anak yang bersangkutan

Pembinaan adalah suatu usaha untuk menjadikan yang dibina hidup sehat jasmaniah dan ruhiniah, sehingga dapat menyesuaikan dan meningkatkan kembali keterampilannya, pengetahuannya serta kepandaiannya dalam lingkungan hidup. ${ }^{2}$ Pembinaan pada dasarnya merupakan suatu aktivitas atau kegiatan yang dilakukan secara sadar, berencana, terarah, dan teratur secara bertanggungjawab dalam rangka menumbuhkan, meningkatkan, dan mengembangkan kemampuan serta sumber-sumber yang tersedia untuk mencapai tujuan. ${ }^{3}$

Jadi yang dimaksud pembinaan adalah suatu usaha untuk meningkatkan dan mengembangkan sikap dan pengetahuan anak didik pemasyarakatan secara terarah dan terartur guna menjadikannnya orang baik dan berguna agar mampu untuk hidup bermasyarakat yang dilakukan oleh petugas lembaga pembinaan khusus anak.

Anak didik tindak pidana adalah anak pidana yaitu anak yang berdasarkan putusan pengadilan menjalani pidana di lapas anak paling lama sampai berumur 18 (delapan belas) tahun. ${ }^{4}$ Anak didik tindak pidana adalah anak negara yaitu anak yang berdasarkan putusan pengadilan diserahkan pada negara untuk didik dan ditempatkan di LAPAS Anak paling lama sampai berumur 18 (delapan belas) tahun. ${ }^{5}$

Jadi yang dimaksud anak didik tindak pidana adalah anak yang telah diputuskan oleh pengadilan uuntuk dibina di LPKA dengan batasan usia 18 (delapan belas) tahun. Sedangkan kriminal adalah kejahatan yaitu tingkah laku yang melanggar hukum dan melanggar norma-norma sosial, sehingga masyarakat menentangnya. ${ }^{6}$

Kriminal atau kejahatan adalah semua bentuk ucapan, perbuatan, dan tingkah laku yang secara ekonomis, politis dan sosial-psikologis sangat merugikan masyarakat, melanggar norma-norma susila, dan menyerang keselamatan warga masyarakat (baik

\footnotetext{
${ }_{1}$ M. Nasir Djamil, Anak Bukan Untuk Di Hukum, (Jakarta: Sinar Grafika, 2013), hlm. 16

${ }^{2}$ Yuyun Nurulaen, Lembaga Pemasyarakatan Masalah \& Solusi, (Bandung: Marja, 2012), hlm. 44

${ }^{3}$ Ibid., hlm. 20

${ }^{4}$ Undang-Undang Republik Indonesia No 12 Tahun 1995 Tentang Pemasyarakatan

${ }^{5}$ lbid., hlm. 6

${ }^{6}$ Kartini Kartono, Patologi Sosial, (Jakarta: Rajawali Pers, 1992), hlm. 134
} 
yang tercantum dalam undang-undang, maupun yang belum tercantum dalam undangundang pidana). ${ }^{7}$

Jadi yang dimaksud pembinaan anak didik tindak pidana kriminal dalam adalah suatu usaha untuk mengembangkan sikap dan pengetahuan anak yang menjalani pidana di LPKA. Melihat keadaan demikian menyebabkan pemerintah perlu segera memikirkan langkah-langkah yang harus diambil dengan menyelamatkan generasi muda yang telah mengalami krisis moral sehingga berani berbuat nekat melakukan tindakan-tindakan yang melanggar hukum dimana perbuatan tersebutcenderung mengarah pada perbuatan kriminal dan berorientasi pada masa depan anak tersebut dalam kehidupan berbangsa dan bernegara. Maka, pemerintah perlu melakukan pembinaan, memberikan bimbingan, pendidikan serta perhatian khusus untuk mereka.

Adapun pembinaan yang dilakukan terhadap anak diserahkan kepada pemerintah. Sehubungan dengan tindak pidana yang dilakukannya pembinaan tersebut lebih diarahkan pada usaha untuk membimbing, mendidik, memperbaiki atau memulihkan keadaan dan tingkah laku anak tersebut, sehingga anak dapat kembali menjalani kehidupan sewajarnya ditengah-tengah masyarakat jika telah menyelesaikan masa hukumannya. Oleh pemerintah pembinaan tersebut diserahkan pada suatu lembaga atau badan yang dinamakan Lembaga Pemasyarakatan berada dibawah Departemen Kehakiman dengan dasar hukum UU No. 12 tahun 1995 tentang pemasyarakatan yang mengkhususkan pada Lembaga Pemasyarakatan anak dalam hal pembinaan atau sekarang yang disebut Lembaga Pembinaan Khusus Anak (LPKA). ${ }^{8}$

Wujud dari suatu keadilan adalah dimana pelaksanaan hak dan kewajiban seimbang. Hak dan kewajiban bagi anak yang melakukan tindak pidana perlu mendapat bantuan dan perlindungan agar seimbang dan manusiawi. Kewajiban bagi anak harus diperlakukan sesuai dengan situasi, kondisi mental dan fisik, keadaan sosial dengan kemampuannya pada usia tertentu. ${ }^{9}$

Kedudukan anak dalam proses peradilan pidana sangat penting, oleh karena itu perlu diatur tentang hak dan kewajibannya. Anak berhak mengetahui tentang tindak pidana yang disangkakan dan berhak didampingi ole penasihat hukum pada setiap tahap peradilan pidana. Penanganan kasus-kasus anak cenderung membekaskan stigma atas diri anak, mulai dari tahap penyidikan (tersangka), penuntutan (terdakwa), persidangan sampai pada pelaksanaan pidana (terpidana). Hal ini sangat merugikan anak.

Undang-Undang Nomor 11 Tahun 2012 tentang Sistem Peradilan Pidana Anak Pasal 85 ayat (2) menyatakan bahwa Anak sebagaimana dimaksud pada ayat (1) berhak memperoleh pembinaan, pembimbingan, pengawasan, pendampingan, pendidikan dan pelatihan, serta hak lain sesuai dengan ketentuan peraturan perundang-

\footnotetext{
${ }^{7}$ Ibid., hlm. 138

${ }^{8}$ Nani Wita Sembiring, "Efektivitas Pembinaan Narapidana Anak Oleh Lembaga Pemasyarakatan Anak Klas II-A Tanjung Gusta Medan", (Sumatra Utara: Disertai Program Ilmu Kesejahteraan Sosial Universitas, 2009), hlm. 5

${ }^{9}$ lbid
} 
undangan. ${ }^{10}$ Selanjutnya pasal 85 ayat (3) menyatakan bahwa LPKA wajib menyelenggarakan pendidikan, pelatihan keterampilan, pembinaan, dan pemenuhan hak lain sesuai dengan ketentuan peraturan perundang-undangan.

Dalam menjalankan tugas dan fungsinya petugas LPKA wajib memperhatikan hak setiap anak dalamproses peradilan pidana sebagaimana diatur dalam Pasal 3 UndangUndang Nomor 11 Tahun 2012 Tentang Sistem Peradilan Pidana yang meliputi: ${ }^{11}$

1. Diperlakukan secara manusiawi dengan memperhatikan kebutuhan sesuai dengan umurnya

2. Dipisahkan dari orang dewasa

3. Memperoleh bantuan hukum dan bantuan lain secara efektif

4. Melakukan kegiatan rekreasional

5. Bebas dari penyiksaan, penghukuman atau perlakuan lain yang kejam, tidak manusiawi, serta merendahkan derajat dan martabatnya

6. Tidak dijatuhi pidana mati atau pidana seumur hidup

7. Tidak ditangkap, ditahan atau dipenjara kecuali sebagai upaya terakhir dan dalam waktu yang paling singkat

8. Memperoleh keadilan di muka pengadilan Anak yang objektif, tindak memihak, dan dalam sidang yang tertutup untuk umum

9. Tidak dipublikasikan identitasnya

10. Memperoleh pendampingan orang tua/Wali/pengasuh dan orang yang dipercaya oleh Anak

11. Memperoleh advokasi sosial

12. Memperoleh kehidupan pribadi

13. Memperoleh aksesibilitas, terutama bagi Anak cacat

14. Memperoleh pendidikan

15. Memperoleh pelayanan kesehatan

16. Memperoleh hak lain sesuai dengan ketentuan perundang-undangan

Petugas LPKA harus pula memperhatikan hak anak yang sedang menjalani pidana sebagaimana diatur dalam Pasal 4 Ayat (1) Undang-Undang Nomor 11 Tahun 2012 Tentang Sistem Peradilan Pidana Anak yang meliputi: ${ }^{12}$

1. Mendapat pengurangan masa pidana

2. Memperoleh asimilasi

3. Memperoleh cuti mengunjungi keluarga

4. Memperoleh pembebasan bersyarat

5. Memperoleh cuti menjelang bebas

6. Memperoleh cuti bersyarat

7. Memperoleh hak hak lain sesuai ketentuan

Di pekanbaru sendiri ada 4 (empat) Lembaga Pemasuyarakatan. dan 1 (satu) Rutan. jadi jumlah seluruhnya dipekanbaru ada 5 (lima), dimana terdiri dari LP Dewasa, LP Wanita, LPKA, LP Terbuka, dan Rutan, sedangkan di antara yang kelima ini hanya satu LPKA yg mengacu kepada SPPA. Sebagai Lembaga Khusus Anak ini hanya fokus untuk

\footnotetext{
10 Undang-Undang Nomor 11 Tahun 2012 tentang Sistem Peradilan Pidana Anak Pasal 85 ayat (2)

${ }^{11}$ Undang-Undang Nomor 11 Tahun 2012 Tentang Sistem Peradilan Pidana Pasal 3

12 Undang-Undang Nomor 11 Tahun 2012 Tentang Sistem Peradilan Pidana Anak Pasal 4 Ayat (1)
} 
membimbing dan terpisah dari orang dewasa sebagaimana yang diamnatkan dari Peraturan Perundang-undangan.

Di dalam Undang-Undang Republik IndonesiaNomor 11 Tahun 2012 Tentang Sistem Peradilan Pidana Anak 85 ayat 2 dan ayat 3 mengatakan bahwa wajib menyelenggarakan pembinaan terhadap anak, baik pembinaan pendidikan, pembinaan keterampilan, dan pembinaan kepribadiaan, namun Pada kenyataannya kewajiban pembinaan di LPKA ini belum berjalan maksimal, terutama pada pembinaan keterampilan dan pembinaan pendidikan. Dalam pembinaan pendidikan di LPKA adalah pendidikan non formal, mencakup kegiatan Paket A untuk sekolah dasar (SD), Paket B untuk sekolah menegah pertama (SMP), dan paket $C$ untuk sekolah menegah atas (SMA) karena kurangnya tenaga pendidik dari luar sedangkan untuk pembinaan keterampilan ini di LPKA, terdiri dari kegiatan Pembinaan Pertanian, Peternakan, Pertukarya, Kesenian, Dan Teknologi Informasi (TI), khusus Teknologi Informasi (TI) tidak berjalan sebagaimana yang diatur. Data dan fakta dilapangan menunjukkan bahwa memang semua LPKA wajib menerapakan ini karena sudah menjadi amanat dari UU Nomor 11 Tahun 2012, dan pada prakteknya memang sudah lama mengalami hal tersebut karena ada beberapa kendala dalam penerapannya.

\section{METODE}

Penelitian yang dilakukan dapat digolongkan kepada penelitian hukum sosiologis yang lazim disebut juga Socio Legal Research berpangkal tolak pada fenomena hukum yang terdapat dalam masyarakat. Penelitian hukum sosiologis bertujuan untuk mengetahui bekerjanya hukum di dalam masyarakat. Dengan demikian, diharapkan peneliti mampu mengungkap efektifitas berlakunya hukum dalam masyarakat dan dapat mengindentifikasi hukum yang tidak tertulis yang berlaku di dalam masyarakat. ${ }^{13}$

Selanjutnya pendekatan penelitian untuk menjawab permasalahan dalam penelitian hukum sosiologis lazimnya iaitu (a). Pendekatan Peraturan Perundang-undangan (Statute Approach) adalah pendekatan yang digunakan untuk menelaah seluruh peraturan perundang-undangan yang berkaitan dengan permasalahan atau isu hukum yang dihadapi, (b), Pendekatan Kasus (case approach) adalah salah satu jenis pendekatan dalam penelitian hukum normatif yang peneliti mencoba membangun argumentasi hukum dalam perspektif kasus konkrit yang terjadi dilapangan, tentunya kasus tersebut erat kaitannya dengan kasus atau peristiwa hukum yang terjadi di lapangan.

Yang menjadi sampel dalam penelitian ini adalah Kepala Bidang Pembinaan Kantor Wilayah Riau Kementerian Hukum dan Hak Asasi Manusia Republik Indonesia, Kepala Pusat Pelayanan Terpadu Perlindungan Perempuan Dan Anak (P2TP2A) Riau, Kasi Pembinaan Anak Pekanbaru, Kasubsi Registrasi LPKA Kelas II Pekanbaru yang tentunya digunakan metode purposive sampling. Sumber data bersumber dari data primer, sekunder dan tertier dan teknik pengumpulan data melalui observasi, wawancara dan kajian kepustakaan. Analisis data dilakukan secara kualitatif dalam analisis tidak menggunakan angka-angka atau statistik atau matematika ataupun yang sejenisnya, namun lebih kepada penjelasan dalam bentuk kalimat yang dipaparkan secara lugas.Penarikan kesimpulan dalam penelitian hukum empiris (sosiologis) dilakukan

${ }^{13}$ Pedoman Penulisan Tesis Program Studi Magister Ilmu Hukum Universitas Lancang Kuning Pekanbaru 2019, hlm 19 
secara induktif, yaitu cara menarik kesimpulan yang bertitik tolak pada hal-hal yang khusus, untuk kemudian menarik kesimpulan atas dasas aspek-aspek yang sama pada hal-hal yang khusus tersebut. Data yang telah dianalisis dan dideskripsikan selanjutnya disimpulkan dengan metode induktif yaitu menyimpulkan dari pernyataan yang bersifat khusus ke dalam pernyataan yang bersifat umum

\section{HASIL DAN PEMBAHASAN}

\section{a. Implementasi Kewajiban Pembinaan Terhadap Pidana Anak Di Lembaga Pembinaan Khusus Anak Pekanbaru Berdasarkan Undang-Undang Republik Indonesia Nomor 11 Tahun 2012 Tentang Sistem Peradilan Pidana Anak}

Terkait dengan hal ini Soejono Dirdjosisworo menyatakan bahwa yang dimaksud dengan pembinaan narapidana adalah segala daya upaya perbaikan terhadap narapidana dengan maksud secara langsung dan minimal menghindarkan pengulangan tingkah laku yang menyebabkan keputusan hakim tersebut. Lapas mempunyai tugas pemasyarakatan dan berfungsi dalam melakukan pembinaan terhadap narapidana atau anak didik, memberikan bimbingan, mempersiapkan sarana dan mengelola hasil kerja, melakukan pemeliharaan keamanan dan tata tertib, serta melakukan urusan tata usaharumah tangga Lapas. Sistem Pemasyarakatan identik dengan reintegrasi sosial, terpidana tidak hanya menjadi obyek tetapi juga menjadi subyek dalam pembinaan. ${ }^{14}$

Lembaga Pembinaan Khusus Anak bukanlah tempat untuk menghukum anak, akan tetapi diharapkan dapat dijadikan tetapi tempat untuk mendidik anak sehingga tidak akan melakukan tindak pidana lagi. Bentuk pembinaan anak dikembangkan dalam rangka memelihara masa depan anak yang bersangkutan. Hal tersebut bukan hal yang mudah untuk diimplementasikan pada semua narapidana anak.

Menurut ibu Meliyani selaku Kepala Bidang Pembinaan Kantor Wilayah Riau Kementerian Hukum dan Hak Asasi Manusia Republik Indonesia mengatakan bahwa untuk Implementasi Kewajiban Pembinaan Terhadap Pidana Anak Di Lembaga Pembinaan Khusus Anak Pekanbaru BerdasarkanUndang-Undang Republik IndonesiaNomor 11 Tahun 2012 Tentang Sistem Peradilan Pidana Anak ini harusnya diutamakan karena pada proses pembinaan hak-hak anak harus terpenuhi, karena mempunyai pengaruh psikologinya. ${ }^{15}$

Menurut bapak Herman selaku Kepala Pusat Pelayanan Terpadu Perlindungan Perempuan Dan Anak (P2TP2A) Riau mengatakan bahwa seharusnya pembinaan harus dilakukan karena hal tersebut merupakan amanat dari undang-undang dan peraturan pemerintah. ${ }^{16}$

${ }^{14}$ Soejono Dirdjosisworo, Sosio Kriminologi: Ilmu-ilmu Sosial dalam Studi Kejahatan, (Bandung: Sinar Baru, 1985), hlm. 24.

${ }^{15}$ Wawancara dengan ibu Meliyani selaku Kepala Bidang Pembinaan Kantor Wilayah Riau Kementerian Hukum dan Hak Asasi Manusia Republik Indonesia, pada tanggal 5 Agustus 2020 di Kota Pekanbaru

${ }^{16}$ Wawancara dengan bapak Herman selaku Kepala Pusat Pelayanan Terpadu Perlindungan Perempuan Dan Anak (P2TP2A) Riau, pada tanggal 11 Agustus 2020 di Kota Pekanbaru 
Menurut ibu Hesty Yunita, S.H selaku Kasi Pembinaan Anak Pekanbaru mengatakan bahwa memang pembinaan sudah dilakukan namun pada kenyataannya jumlah anggaran dan tenaga pendidik yang tidak memadai. ${ }^{17}$

Menurut bapak Budi Hamidi, Amd.,S.H.,M.H selaku Kasubsi Registrasi LPKA Kelas II Pekanbaru mengatakan bahwa dalam hal ini pembinaan terhadap anak di lembaga sudah dijalankan, hal ini dilihat dari berbagai kegiatan yang diselenggarakan. Seperti kesenian, olahraga, kegiatan beribadah, dan lain-lain sebagainya. ${ }^{18}$

Muladi dan Barda Nawawi mengemukakan bahwa perlindungan hukum bagi anak dalam proses peradilan tidak dapat dilepaskan dari apa yang sebenarnya tujuan atau dasar pemikiran dari peradilan anak (juvenile justice) itu sendiri yang bertolak dari dasar pemikiran baru yang dapat ditentukan apa dan bagaimana hakikat wujud dari perlindungan hukum yang sifatnya diberikan kepada anak. Tujuan dan dasar pemikiran dari peradilan anak tidak dapat dilepaskan dari tujuan utama untuk mewujudkan kesejahteraan anak yang pada dasarnya merupakan bagian integral dari kesejahteraan sosial. Kesejahteraan atau kepentingan anak berada di bawah kepentingan masyarakat, tetapi justru harus dilihat bahwa mendahulukan atau mengutamakankesejahteraan dan kepentingan anak itu pada hakikatnya merupakan bagian dari usaha mewujudkan kesejahteraan sosial. ${ }^{19}$

Pemasyarakatan berada di depan, tengah, dan penghujung dalam sistem peradilan pidana. Apabila kita mengikuti apa yang dipahami tentang sistem peradilan pidana, maka posisi sistem pemasyarakatan hanya berada di penghujung sistem. Dengan kata lain, pemasyarakatan hanyalah tempat menahan terpidana setelah diproses secara hukum oleh polisi, jaksa, dan pengadilan. Undang-Undang Nomor 12 Tahun 1995 tentang Pemasyarakatan juga menyebutkan bahwa pemasyarakatan merupakan penghujung di dalam Sistem Peradilan Pidana.

Dalam kenyataannya, pemasyarakatan tidaklah sistem yang hanya berperan di penghujung sistem peradilan pidana. Sebagaimana telah dijelaskan, Rutan dan Bapas jauh berperan sebelum seseorang diputus menjadi terpidana oleh pengadilan. Sehingga kenyataan ini mengharuskan masyarakat, khususnya dikaitkan dengan rencana pembangunan hukum nasional, sebagaimana diperlihatkan oleh RKUHP, maka posisi sistem pemasyarakatan semakin jelas tidak hanya sebagai penghujung sistem peradilan pidana, namun juga di awal.Pasal 54 RKUHP menyatakan bahwa tujuan pemidanaan adalah:

a. Mencegah dilakukannya indak pidana dengan menegakkan norma hukum demi pengayoman masyarakat;

b. Memasyarakatkan terpidana dengan mengadakan pembinaan sehingga menjadi orang yang baik dan berguna;

c. Menyelisaikan konflik yang ditimbulkan oleh tindak pidana, memulihkan keseimbangan, dan mendatangkan rasa damai dalam masyarakat;

d. Membebaskan rasa bersalah pad terpidana.

\footnotetext{
${ }^{17}$ Wawancara dengan ibu Hesty Yunita, S.H selaku Kasi Pembinaan Anak Pekanbaru, pada tanggal 7 Agustus 2020 di Kota Pekanbaru

${ }^{18}$ Wawancara dengan bapak Budi Hamidi, Amd.,S.H.,M.H selaku Kasubsi Registrasi LPKA Kelas II Pekanbaru, pada tanggal 14 Agustus 2020 di Kota Pekanbaru

${ }^{19}$ Barda Nawawi dan Muladi, Bunga Rampai Hukum Pidana, (Bandung: Alumni, 1992), hlm. 11.
} 
Selain itu disebutkan dalam Pasal 54 ayat (2) bahwa pemdidanaan tidak dilaksudkan untuk menderitakan dan merendahkan martabat manusia. Dan ditengah proses peradilan pidana. Pada aspek filosofis, RKUHP justru menjelaskan pemasyarakatan adalah tujuan penghukuman yang harus diinternalisasikan oleh Kepolisian, Kejaksaan, dan Lembaga Pengadilan.

Sejumlah masalah yang muncul dalam sistem pemasyarakatan dewasa ini, khususnya masalah overcrowded sangat terkait dengan peran yang seharusnya dapat dimainkan oleh sub sistem peradilan pidana lainnya. Pada kenyataan sekarang ini memperlihatkan adanya kecenderungan sub sistem peradilan pidana lainnya untuk menahan dan memenjarakan sebanyak mungkin orang. Hal ini dibuktikan dengan masih minimnya keinginan polisi, jaksa, dan hakim menggunakan kewenangan yang mereka miliki secara informal untuk mengalihkan seseorang dari penahanan atau pemenjaraan. Seperti yang telah diungkapkan sebelumnya bahwa perkembangan filosofi pemasyarakatan saat ini lebih mengarah pada deinstitusionalisasi penghukuman. Rencana pembangunan hukum di Indonesia pun mempertegas hal tersebut di dalam Rancangan Kitab Undang-Undang Hukum Pidana. Dalam implemntasinya tentu harus mendapatkan dukungan dari sub sisem peradilan pdana lainnya.

Pada prinsipnya perlakuan yang diperoleh tersebut tidak boleh mempengaruhi mental seperti menakut-nakuti, mengancam apalgi melakukan tindakan kekerasan. Petugas dalam menjalankan perannya tidak diperbolehkan menggunakan seragam. Petugas juga dilarang keras melakukan tindakan- tindakan yang dapat menimbulkan kebencian atau menimbulkan keinginan untuk balas dendam bagi anak-anak terhadap petugas. Selain itu, kesempatan untuk selalu bermain dan belajar harus dikedepankan serta tingkat interaksi dengan lingkungan dan keluarga harus lebih sering direncanakan. Pendidikan anak harus senantiasa tersedia hingga kejenjang yang paling tinggi baik formal atau non-formal. Keterampilan atau pernjurusan keterampilan harus disediakan sesuai dengan bakat dan minat anak atau disesuaikan dengan kemajuan masyarakat, misalnya diarahkan untuk menguasai teknologi.

Pembinaan anak pidana harus berorientasi pada nilai ketuhanan karena merupakan wujud ketaqwaan kepada Tuhan Yang Maha Esa. Anak (termasuk anak pidana) harus dianggap sebagai amanah yang harus di jaga dan merupakan tanggung jawab orang tua, keluarga, masyarakat dan pemerintah dan negara. Pembinaan anak pidana harus berorientasi pada nilai kemanusiaan harus sesuai dengan perlindungan anak pidana.

Pembinaan anak pidana harus memiliki program yang harus dapat memanusiakan anak, mengasuh, membina, membimbing anak pidana. Pembinaan anak pidana harus berorientasi pada nilai kemasyarakatan menurut penulis sesuai dengan penyelenggaraan perlindungan anak. Para pihak yaitu negara, Pembina atau petugas, keluarga, dan masyarakat harus rela berkorban demi terselenggaranya perlindungan dan pemenuhan hak anak pidana. Hal ini merupakan wujud dari nilai Persatuan Indonesia.

Berkaitan dengan nilai demokratik, pembinaan anak pidana harus sesuai dengan nilai dan prinsip musyawarah untuk mencapai mufakat dalam rangka perlindungan anak, mengedepankan kepentingan terbaik bagi anak. Pembaharuan pembinaan anak pidana dalam rangka mewujudkan kepentingan terbaik bagi anak juga harus mewujudkan restorative justice. John Braithwhite mengemukakan restorative justice sebagai proses dimana semua pihak yang terlibat pelanggaran tertentu bersama-sama memecahkan 
secara kolektif bagaimana untuk menghadapi akibat pelanggaran dan implikasinya pada waktu yang akan datang. Restorative justice bertujuan untuk memulihkan harmoni atau keseimbangan karena hukum telah ditegakkan. ${ }^{20}$ Memulihkan harmoni atau keseimbangan secara an sich saja tidak cukup, oleh karena itu "memulihkan keseimbangan" hanya dapat diterima sebagai gagasan mewujudkan keadilan jika "keseimbangan" secara moral antara pelaku dan korban yang ada sebelumnya adalah keseimbangan yang pantas. Sebagai konsep pemidanaan tentunya tidak hanya terbatas pada ketentuan hukum pidana (formil dan materiil).

Menurut pandangan restorative justice, penanganan kejahatan yang terjadi tidak hanya menjadi tanggung jawab Negara akan tetapi juga merupakan tanggung jawab masyarakat. Oleh karena itu, konsep restorative justice di bangun berdasarkan pengertian kerugian yang ditimbulkan oleh kejahatan akan dipulihkan kembali, baik kerugian yang di derita oleh korban maupun kerugian yang di tanggung oleh masyarakat. Pelaksanaan konsep restorative justice memberi banyak kesempatan kepada masyarakat untuk berperan aktif dalam penyelesaian masalah tindak pidana.

Pada prinsipnya perlakuan yang diperoleh tersebut tidak boleh mempengaruhi mental seperti menakut-nakuti, mengancam apalgi melakukan tindakan kekerasan. Petugas dalam menjalankan perannya tidak diperbolehkan menggunakan seragam. Petugas juga dilarang keras melakukan tindakan- tindakan yang dapat menimbulkan kebencian atau menimbulkan keinginan untuk balas dendam bagi anak-anak terhadap petugas. Selain itu, kesempatan untuk selalu bermain dan belajar harus dikedepankan serta tingkat interaksi dengan lingkungan dan keluarga harus lebih sering direncanakan. Pendidikan anak harus senantiasa tersedia hingga kejenjang yang paling tinggi baik formal atau non-formal. Keterampilan atau pernjurusan keterampilan harus disediakan sesuai dengan bakat dan minat anak atau disesuaikan dengan kemajuan masyarakat, misalnya diarahkan untuk menguasai teknologi.

Pembinaan anak pidana harus berorientasi pada nilai ketuhanan karena merupakan wujud ketaqwaan kepada Tuhan Yang Maha Esa. Anak (termasuk anak pidana) harus dianggap sebagai amanah yang harus di jaga dan merupakan tanggung jawab orang tua, keluarga, masyarakat dan pemerintah dan negara. Pembinaan anak pidana harus berorientasi pada nilai kemanusiaan harus sesuai dengan perlindungan anak pidana.

Pembinaan anak pidana harus memiliki program yang harus dapat memanusiakan anak, mengasuh, membina, membimbing anak pidana. Pembinaan anak pidana harus berorientasi pada nilai kemasyarakatan menurut penulis sesuai dengan penyelenggaraan perlindungan anak. Para pihak yaitu negara, Pembina atau petugas, keluarga, dan masyarakat harus rela berkorban demi terselenggaranya perlindungan dan pemenuhan hak anak pidana. Hal ini merupakan wujud dari nilai Persatuan Indonesia.

Berkaitan dengan nilai demokratik, pembinaan anak pidana harus sesuai dengan nilai dan prinsip musyawarah untuk mencapai mufakat dalam rangka perlindungan anak, mengedepankan kepentingan terbaik bagi anak. Pembaharuan pembinaan anak pidana dalam rangka mewujudkan kepentingan terbaik bagi anak juga harus mewujudkan restorative justice. John Braithwhite mengemukakan restorative justice sebagai proses

${ }^{20}$ John Braithwaite, Restorative Justice \& Responsive Regulation, (New York, Oxford University Press, Inc, 2002), hlm 45 
dimana semua pihak yang terlibat pelanggaran tertentu bersama-sama memecahkan secara kolektif bagaimana untuk menghadapi akibat pelanggaran dan implikasinya pada waktu yang akan datang. Restorative justice bertujuan untuk memulihkan harmoni atau keseimbangan karena hukum telah ditegakkan. ${ }^{21}$ Memulihkan harmoni atau keseimbangan secara an sich saja tidak cukup, oleh karena itu "memulihkan keseimbangan" hanya dapat diterima sebagai gagasan mewujudkan keadilan jika "keseimbangan" secara moral antara pelaku dan korban yang ada sebelumnya adalah keseimbangan yang pantas. Sebagai konsep pemidanaan tentunya tidak hanya terbatas pada ketentuan hukum pidana (formil dan materiil).

Menurut pandangan restorative justice, penanganan kejahatan yang terjadi tidak hanya menjadi tanggung jawab Negara akan tetapi juga merupakan tanggung jawab masyarakat. Oleh karena itu, konsep restorative justice di bangun berdasarkan pengertian kerugian yang ditimbulkan oleh kejahatan akan dipulihkan kembali, baik kerugian yang di derita oleh korban maupun kerugian yang di tanggung oleh masyarakat. Pelaksanaan konsep restorative justice memberi banyak kesempatan kepada masyarakat untuk berperan aktif dalam penyelesaian masalah tindak pidana.

\section{B. Akibat Hukum Implementasi Kewajiban Pembinaan Terhadap Pidana Anak Di Lembaga Pembinaan Khusus Anak Pekanbaru Berdasarkan Undang-Undang Republik Indonesia Nomor 11 Tahun 2012 Tentang Sistem Peradilan Pidana Anak}

Lembaga pemasyarakatan sebagai bagian dari sistem peradilan pidana merupakan wadah bagi narapidana untuk menjalani masa pidananya serta memperoleh berbagai bentuk pembinaan dan keterampilan. Melalui pembinaan dan keterampilan ini diharapkan dapat mempercepat proses resosialisasi narapidana. ${ }^{22}$ Lembaga pemasyarakatan melalui sistem pemasyarakatan memberikan perlakuan yang lebih manusiawi kepada narapidana dengan pola pembinaan. Pembinaan narapidana adalah sebuah sistem. Sebagai suatusistem, maka pembinaan narapidana mempunyai beberapa komponen yang bekerja saling berkaitan untuk mencapai suatu tujuan. ${ }^{23}$

Sistem pemasyarakatan diharapkan mampu melakukan resosialisasi terhadap narapidana dan anak didik pemasyarakatan yang melakukan pembinaan di lembaga pemasyarakatan. Adanya model pendidikaan narapidana dan anak didik pemasyarakatan di dalam Lapas tidak terlepas dari sebuah dinamika, yang bertujuan untuk memberikan lebih banyak bekal bagi narapidana dan anak didik pemasyarakatan dalam menjalani kehidupan setelah selesai menjalani masa hukuman atau bebas.

Pendidikan bagi para narapidana dan anak didik pemasyarakatan bertujuan untuk memberi bekal mereka ketika keluar dari Lembaga pemasyarakatan. Oleh sebab itu pendidikan menjadi penyebab positif untuk mengurangi tingkat kejahatan. Semakin banyak orang mengenyam pendidikan maka pengangguran dan angka kejahatan semakin berkurang. Kondisi ini menjadikan sekolah mempunyai manfaat sosial yang tak terhingga bagi masyarakat.

${ }^{21}$ John Braithwaite, Restorative Justice \& Responsive Regulation, (New York, Oxford University Press, Inc, 2002), hlm 45

22 Djisman Samosir, Fungsi Pidana Penjara dalam Sistem Pemidanaan di Indonesia, (Bandung: Bina Cipta, 1992), hlm. 82.

${ }^{23}$ Harsono HS, Sistem Baru Pembinaan Narapidana, (Jakarta: Djambatan, 1995), hlm. 5. 
Hukum diciptakan untuk mengatur antara kepentingan-kepentingan yang satu dengan yang lain tidak berbenturan atau tidak terjadi konflik antara satu yang lainnya, dan bertujuan untuk mejamin ketertiban, ketentraman dan keadilan di dalam tatanan kehidupan bermasyarakat. Terhadap anak sebagai pelaku akan tindakan pidana (berkonflik dengan hukum), bukan berarti anak tersebut harus diasingkan/dijauhi, serta dikucilkan dari pergaulannya.

Dapat dimungkinkan seorang anak tidak bisa mengerti dan mengetahui akan apa yang diperbuatnya, sehingga harus dianggap sebagai manusia yang tetap mendapatkan hak-haknya. Karena itu, sangat perlu perlu dilakukan pemulihan dan pembinaan terhadap kejiwaan dan mentalnya, dan akhirnya menyadari apa yang dilakukannya adalah salah, serta dapat memberikan suatu efek jera agar dirinya tidak mengulangi kesalahannya.

Dijelaskan dalam Undang-Undang Nomor 12 tahun 1995 tentang Pemasyarakatan bahwa Sistem Pemasyarakatan merupakan suatu tatanan megenai arah dan batas serta cara pembinaan Warga Binaan Pemasyarakatan berdasarkan Pancasila yang dilaksanakan secara terpadu antara pembina, yang dibina, dan masyarakat untuk meningkatkan kualitas Warga Binaan Pemasyarakatan agar menyadari kesalahan, memperbaiki diri, dan tidaakmengulangi tindak pidana sehingga dapat diterima kembali oleh lingkungan masyarakat, dapat aktif berperan dalam pembangunan, dan dapat hidup secara wajar sebagai warga yang baik dan bertanggungjawab.

Dalam sistem pemasyarakatan menekankan kepada aspek pembinaan secara menyeluruh, artinya tahanan, narapidana/warga binaan pemasyarakatan berhak mendapatkan pembinaan rohani dan jasmani serta dijamin hak-hak mereka untuk menjalankan ibadah, berhubungan dengan pihak luar baik keluarga maupun pihak lain, serta memperoleh informasi dan hak-hak lainnya. ${ }^{24}$

Menurut Muladi, Pemasyarakatan merupakan suatu proses pembinaan narapidana yang sering disebut theurapetics procces, yakni membina narapidana dalam arti menyembuhkan seseorang yang tersesat hidupnya karena kelemahan-kelemahan tertentu. ${ }^{25}$ Pembinaan narapidana menurut sistem pemasyarakatan terdiri dari pembinaan didalam lembaga yang meliputi pendidikan agama; kesenian; kepramukaan; latihan kerja; asimilasi, sedangkan pembinaan di luar lembaga antara lain bimbingan selama terpidana mendapat pidana bersyarat; penelitian kemasyarakatan.

Dengan demikian maka sistem pemasyarakatan secara tegas menyatakan bahwa setiap narapidana mempunyai hak-hak yang melekat pada dirinya seperti hak untuk surat menyurat; hak untuk dikunjungi/mengunjungi; remisi;cuti; asimilasi serta lepas bersyarat; melakukan ibadah sesuai dengan agamanya; menyampaikan keluhan; mendapatkan pelayanan kesehatan; mendapatkan upah atas pekerjaan; memperoleh bebas bersyarat.

Tempat di mana anak didik pemasyarakatan, mendapatkan suatu pembinaan menyeluruh dinamakan Lembaga Pemasyarakatan anak, hal ini tercantum dalam ketentuan pasal 1 angka 3 Undang-Undang Pemasyarakatan, dalam melaksanakan

24 Etti Kusumawati, "Pelaksanaan Pembinaan Narapidana Dan Pembebasan Bersyarat Di Rumah Tahanan Negara (Studi Di Rumah Tahanan Negara Bantul)", Skripsi Tidak Diterbitkan, (Yogyakarta: Universitas Widya Mataram, 2012), hlm.16.

25 Muladi, Hak Asasi Manusia, Politik Dan Sistem Peradilan Pidana, (Semarang: Badan Penerbit Universitas Diponegoro, 2002), hlm. 224. 
pembinaan pemasyarakatan perlu didasarkan suatu asas sistem pembinaan pemasyarakatan, sesuai dengan bunyi Pasal 5 UndangUndang Nomor 12 Tahun 1995 tentang Pemasyarakatan, menyebutkan antara lain: ${ }^{26}$

a. Pengayoman warga bina pemasyarakatan harus selalu dilindungi dari lapisan masyarakat terhadap segala kemungkinan terjadinya/ diulanginya tindakan pidana yang dilakukannya, sehingga perlu diberikan perlakuan yang baik.

b. Persamaan akan perlakuan dan pelayanan Pembina pemasyarakatan memberikan perlakuan dan pelayanan yang benarbenar sama tanpa menbedakan suku, agama, ras dan antar golongan terhadap warga binaannya, asas ini tertulis dalam pasal 27 ayat (1) UUD 1945, Bahwa semua orang mempunyai kedudukan yang sama di depan hukum dan pemerintahan.

c. Pendidikan Penyelenggaraan pembinaan harus selalu dilaksanakan dengan dasar mendidik dan membimbing mereka. Pendidikan dan bimbingan dilaksanakan berdasarkan Pancasila, antara lain penamaan jiwa pendidikan kerohanian, kekeluargaan, keterampilan, dan kesempatan untuk menunaikan ibadah

d. Pembimbingan Bentuk bimbingan yang mengarahkan agar kelak suatu saat selesai menjalani masa hukuman di Lembaga Pemasyarakatan (LAPAS), menjadi orang yang berguna,baik bagi dirinya sendiri, lingkungannya dan masyarakat, serta tidak mengulangi kesalahannya.

e. Penghormatan akan harkat dan martabat manusia Melaksanakan pembinaan tetap harus memperlakukan sebagaimana layaknya manusia, meskipun sudah dianggap sebagai orang yang melakukan kesalahan, baik besar ataupun kecil kesalahannya dan macam apapun dilakukannya, mereka tetap manusia.

f. Kehilangan kemerdekaan merupakan bentuk penderitaan Selama narapidana anak berada di LAPAS, kemerdekaan serasa dibatasi, dan harus menjalani pidana penjara, ataupun kurungan.

g. Hak untuk tetap berhubungan dengan keluarga dan orang-orang tertentu tetap terjamin Berada di dalam Lapas, tetap dijamin haknya untuk berhubungan/berdekatan dengan keluargnya dan orang-orang tertentu, pada prinsipnya pembinaan tidak boleh dikucilkan/ diasingkan sama sekali dengan masyarakat. ${ }^{27}$

Hak-Hak Narapidana dan Anak Didik Pemasyarakatan, adalah sebagai berikut:

a. Melakukan ibadah sesuai dengan agama dan kepercayaannya; ${ }^{28}$

Ibadah sebagaimana dimaksud adalah ibadah yang dilaksanakan di dalam Lapas maupun di luar Lapas sesuai dengan program pembinaan. Disetiap Lapas wajib disediakan petugas untuk memberikan pendidikan dan bimbingan keagamaan. Kepala Lapas dapat melakukan kerja sama dengan instansi terkait, organisasi kemasyarakatan, atau perorangan. Setiap narapidana wajib mengikuti program Pendidikan dan Bimbingan agama sesuai dengan agama dan kepercayaannya. ${ }^{29}$

\footnotetext{
${ }^{26}$ Gatot Supramono, Hukum Acara Pengadilan Anak, (Jakarta: Djambatan, 2007), hlm 5

${ }^{27}$ Ibid

${ }^{28}$ Lihat Pasal 2-4 Peraturan Pemerintah RI Nomor 32 Tahun 1999 Jo PP No.28 tahun 2006 tentang Syarat dan Tata Cara Pelaksanaan Hak Warga Binaan Pemasyarakatan.

${ }^{29}$ Achmad Surya, "Kebijakan Pemberian Remisi Kepada Narapidana Tindak Pidana Korupsi Di Lembaga Pemasyarakatan Kelas IIB Sleman”, Tesis Tidak Diterbitkan, Program PascaSarjana, (Yogyakarta: Universitas Gadjah Mada, 2012), hlm.54.
} 
b. Mendapatkan perawatan, baik perawatan jasmani maupun rohani; ${ }^{30}$

Perawatan rohani diberikan melalui bimbingan rohani dan pendidikan pekerti. Pada setiap Lapas wajib disediakan petugas bimbingan rohani dan pendidikan budi pekerti. Dalam melaksanakan bimbingan rohani dan pendidikan budi pekerti Kalapas dapat bekerja sama dengan Instansi terkait, Badan Kemasyarakatan atau perorangan. Setiap narapidana berhak mendapatkan perawatan jasmani, berupa pemberian kesempatan melakukan berolah raga dan rekreasi, pemberian perlengkapan pakaian dan pemberian perlengkapan tidur dan mandi.Narapidana wajib memakai pakaian seragam yang telah ditetapkan. ${ }^{31}$

c. Mendapatkan pendidikan dan pengajaran; ${ }^{32}$

Lapas wajib melaksanakan kegiatan pendidikan dan pengajaran bagi narapidana. Pada setiap Lapas wajib disediakan petugas pendidikan dan pengajaran bekerja sama dengan instansi pemerintah yang lingkup tugasnya meliputi bidang pendidikan dan kebudayaan dan badan kemasyarakatan yang bergerak dibidang pendidikan dan pengajaran. Pendidikan dan pengajaran bagi narapidana dilaksanakan di dalam Lapas dan di luar Lapas. Pendidikan dan pengajaran di dalam Lapas diselenggarakan menurut kurikulum yang berlaku pada lembaga pendidikan yang sederajat. Setiap narapidana yang berhasil menyelesaikan pendidikan dan pengajaran, berhak memperoleh surat tanda tamat belajar dari instansi yang berwenang. ${ }^{33}$

d. Mendapatkan pelayanan kesehatan dan makanan yang layak; ${ }^{34}$

Untuk menyediakan pelayanan kesehatan yang layak maka pada setiap Lapas disediakan poliklinik beserta fasilitasnya dan disediakan sekurang- kurangnya seorang dokter dan seorang tenaga kesehatan lainnya. Dalam hal narapidana memerlukan perawatan lebih lanjut, maka dokter Lapas dapat memberikan rekomendasi kepada Kepala Lapas agar pelayanan kesehatan dilakukan di Rumah Sakit Umum Pemerintah di Luar Lapas. Pelayanan bagi narapidana yang berobat dirumah sakit umum pemerintah di luar Lapas harus mendapat izin tertulis dari Kepala Lapas. Biaya perawatan bagi narapidana yang berobat di luar Lapas dibebankan kepada negara.

Setiap narapidana berhak mendapatkan makanan dan minuman sesuai dengan jumlah kalori yang memenuhi syarat kesehatan. Narapidana yang sakit, hamil, atau menyusui berhak mendapatkan makanan tambahan sesuai dengan petunjuk dokter. Makanan tambahan juga diberikan kepada narapidana yang melakukan jenis pekerjaan tertentu. Mutu dan jumlah bahan makanan untuk kebutuhan narapidana harus sesuai dengan ketentuan peraturan perundang-undangan yang berlaku.

\footnotetext{
${ }^{30}$ Lihat Pasal 5-8 Peraturan Pemerintah RI Nomor 32 Tahun 1999 Jo PP No.28 Tahun 2006 tentang Syarat dan Tata Cara Pelaksanaan Hak Warga Binaan Pemasyarakatan.

${ }^{31}$ Achmad Surya, "Kebijakan Pemberian Remisi Kepada Narapidana Tindak Pidana Korupsi Di Lembaga Pemasyarakatan Kelas IIB Sleman",..., hlm.55.

32 Lihat Pasal 9-13 Peraturan Pemerintah RI Nomor 32 Tahun 1999 Jo PP No.28 Tahun 2006 tentang Syarat dan Tata Cara Pelaksanaan Hak Warga Binaan Pemasyarakatan.

${ }^{33}$ Achmad Surya, , "Kebijakan Pemberian Remisi Kepada Narapidana Tindak Pidana Korupsi Di Lembaga Pemasyarakatan Kelas IIB Sleman",..., hlm.55

${ }^{34}$ Lihat Pasal 14-25 Peraturan Pemerintah RI Nomor 32 Tahun 1999 Jo PP No.28 Tahun 2006 Tentang Syarat dan Tata Cara Pelaksanaan Hak Warga Binaan Pemasyarakatan.
} 
e. Menyampaikan keluhan; 35

Setiap narapidana berhak menyampaikan keluhan kepada Kepala Lapas atas perlakuan petugas atau sesama narapidana terhadap dirinya. Keluhan tersebut harus disampaikan apabila perlakuan tersebut benar-benar dapat mengganggu hak-hak narapidana yang bersangkutan. Keluhan dapat disampaikan secara lisan atau tulisan dengan memperhatikan Tata Tertib Lapas.

f. Mendapatkan bahan bacaan dan mengikuti siaran media massa lainnya yang tidak dilarang; ${ }^{36}$

Setiap Lapas harus menyediakan bahan bacaan, media massa yang berupa media cetak dan media elektronik. Bahan bacaan dan media massa harus menunjang program pembinaan kepribadian dan kemandirian narapidana dan tidak bertentangan dengan ketentuan peraturan perundangan yang berlaku. Setiap narapidana yang berkeinginan membawa dan mendapat bahan bacaan atau media informasi media massa dari luar Lapas harus mendapatkan izin dari Kepala Lapas. Setiap Lapas harus menyediakan sekurang-kurangnya 1 buah pesawat televisi, 1 buah radio penerima, dan media elektronik lain yang tidak bertentangan dengan peraturan perundang-undangan. Narapidana dilarang membawa pesawat televisi, radio, atau media elektronik ke dalam Lapas untuk kepentingan pribadi.

g. Mendapatkan upah atau premi atas pekerjaan yang dilakukan; ${ }^{37}$

Setiap narapidana yang bekerja berhak mendapat upah atau premi. Besarnya upah atau premi sebagaimana dimaksud sesuai dengan peraturan perundang-undangan yang berlaku. Upah atau premi yang diterima narapidana dititipkan dan dicatat di Lapas. Upah atau premi yang diberikan kepada narapidana yang bersangkutan, apabila diperlukan untuk memenuhi keperluan yang mendasar selama berada di Lapas atau untuk biaya pulang setelah menjalani masa pidana.

h. Menerima kunjungan keluarga, penasehat hukum atau orang tertentu lainnya;38

Setiap narapidana yang bekerja berhak menerima kunjungan dari keluarga, penasehat hukum, atau orang tertentu lainnya. Setiap Lapas wajib menyediakan sekurang-kurangnya 1 (satu) ruangan khusus untuk menerima kunjungan. Petugas Lapas yang bertugas ditempat kunjungan, wajib memeriksa dan meneliti keterangan identitas diri pengunjung dan menggeledah pengunjung dan memeriksa barang bawaannya.

i. Mendapatkan pengurangan masa pidana (remisi); 39

Pengertian remisi yaitu pengurangan masa menjalani pidana yang diberikan kepada Narapidana dan Anak Pidana yang memenuhi syarat-syarat yang ditentukan dalam peraturan perundang-undangan. Setiapnarapidana selama menjalani masa pidana dan berkelakuan baik berhak mendapatkan remisi. Remisi

\footnotetext{
35 Lihat Pasal 26 Peraturan Pemerintah RI Nomor 32 Tahun 1999 Jo PP No.28 Tahun 2006 tentang Syarat dan Tata Cara Pelaksanaan Hak Warga Binaan Pemasyarakatan.

${ }^{36}$ Lihat Pasal 27-28 Peraturan Pemerintah RI Nomor 32 Tahun 1999 Jo PP No.28 Tahun2006 tentang Syarat dan Tata Cara Pelaksanaan Hak Warga Binaan Pemasyarakatan

37 Lihat Pasal 29 Peraturan Pemerintah RI Nomor 32 Tahun 1999 Jo PP Nomor 28 Tahun 2006 tentang Syarat dan Tata Cara Pelaksanaan Hak Warga Binaan Pemasyarakatan.

38 Lihat Pasal 30-33 Peraturan Pemerintah RI Nomor 32 Tahun 1999 Jo PP Nomor 8 Tahun 2006 tentang Syarat dan Tata Cara Pelaksanaan Hak Warga Binaan Pemasyarakatan.

${ }^{39}$ Lihat Pasal 34-35 Peraturan Pemerintah RI Nomor 32 Tahun 1999 Jo PP Nomor 8 Tahun 2006 tentang Syarat dan Tata Cara Pelaksanaan Hak Warga Binaan
} 
sebagaimana dimaksud di atas dapat ditambah apabila selama menjalani pidana, yang bersangkutan :

1) Berbuat jasa kepada negara;

2) Melakukan perbuatan yang bermanfaat bagi negara atau kemanusiaan atau

3) Melakukan perbuatan yang membantu kegiatan Lapas.

Remisi sangat penting terhadap sistem pelaksanaan pidana penjara khususnya pemasyarakatan. Hal ini menyangkut keberhasilan dari petugas dalam membina para narapidana. Dalam pelaksanaan pidana penjara di Indonesia, remisi mempunyai kedudukan yang sangat penting dan strategis karena apabila narapidana tidak berkelakuan baik maka narapidana tidak akan mendapatkan remisi. Jadi remisi menjadi tolak ukur keberhasilan dari pembinaan yang dilakukan oleh petugas. Macam-macam remisi: ${ }^{40}$

4) Remisi Umum;

Yang dimaksud dengan remisi umum adalah pengurangan masa pidana yang diberikan kepada narapidana dan anak pidana pada peringatan Proklamasi Kemerdekaan Republik Indonesia yang jatuh pada tanggal 17 Agustus. Penghitungan lamanya masa menjalani pidana sebagai dasar untuk menetapkan besarnyaremisi umum dihitung sejak tanggal penahanan sampai dengan hari peringatan Proklamasi Kemerdekaan Republik Indonesia yaitu tanggal 17 Agustus. Apabila dalam hal penahanan terputus, maka penghitungan penetapan lamanya masa menjalani pidana dihitung dari sejak penahanan yang terakhir.

5) Remisi Khusus;

Remisi khusus adalah pengurangan masa pidana yang diberikan kepada narapidana dan anak pidana pada hari besar keagamaan yang dianut oleh yang bersangkutan dan dilaksanakan sebanyak- banyaknya 1 (satu) kali dalam setahun bagi masing-masing agama. Penghitungan lamanya masa menjalani pidana sebagai dasar untuk menetapkan besarnya remisi khusus dihitung sejak tanggal penahanan sampai dengan hari besar keagamaan yang dianut oleh Narapidana dan Anak Didik Pemasyarakatan yang bersangkutan. Apabila dalam hal penahanan terputus, maka penghitungan penetapan lamanya masa menjalani pidana dihitung dari sejak penahanan yang terakhir.

6) Remisi Tambahan;

Remisi tambahan yaitu pengurangan masa pidana yang diberikan kepada narapidana atau anak didik pemasyarakatan atas perbuatan baik. Besarnya remisi tambahan yang dapat diperoleh karena melakukan perbuatan baik adalah sebesar $1 / 2$ (satu per dua) dari remisi umum yang diperoleh pada tahun yang bersangkutan.

j. Mendapatkan kesempatan berasimilasi termasuk cuti mengunjungi keluarga; ${ }^{41}$ Pengertian asimilasi yaitu proses pembinaan narapidana dan anak didik pemasyarakatan yang dilaksanakan dengan membaurkan narapidana dan anak

40 Didik Setiawan, "Syarat Dan Tata Cara Pemberian Hak-Hak Hukum Bagi Warga Binaan Pemasyarakatan Di Rumah Tahanan Negara Yogyakarta", Skripsi tidak diterbitkan, Fakultas Hukum, (Yogyakarta: Universitas Widya Mataram Yogyakarta, 2011), hlm. 33.

${ }^{41}$ Lihat Pasal 36-42 Peraturan Pemerintah RI Nomor 32 Tahun 1999 Jo PP Nomor 28 Tahun 2006 tentang Syarat dan Tata Cara Pelaksanaan Hak Warga Binaan Pemasyarakatan. 
didik pemasyarakatan tersebut di dalam kehidupan masyarakat. Narapidana mendapatkan asimilasi bila telah menjalani $1 / 2$ masa pidananya, mengikuti program pembinaan dengan baik, dan berkelakuan baik. Asimilasi dapat berupa kegiatan pendidikan, latihan keterampilan, kegiatan sosial, kegiatan bekerja pada pihak ketiga, bekerja mandiri dan pembinaan lainnya di luar Lapas. Kegiatan asimilasi ini diberitahukan secara tertulis kepada Pemerintah Daerah, Kepolisian, dan hakim pengawas serta pengamat setempat. Cuti mengunjungi keluarga dapat diberikan kepada narapidana, berupa kesempatan berkumpul bersama keluarga ditempat kediamannya. Cuti sebagaimana dimaksud diberikan paling lama 2 (dua) hari atau 2x24 (dua kali dua puluh empat) jam. Izin cuti mengunjungi keluarga diberikan oleh Kepala Lapas dan wajib diberitahukan kepada Kepala Bapas setempat.

k. Mendapatkan pembebasan bersyarat; 42

Pembebasan bersyarat adalah proses pembinaan narapidana di luar lapas. Pembebasan bersyarat bagi narapidana diberikan setelah menjalani pidana sekurang-kurangnya 2/3 (dua pertiga) masa pidana tersebut tidak kurangdari 9 (sembilan) bulan. Dalam menentukan pelepasan bersyarat, ditentukan pula suatu masa percobaan, serta syarat-syarat yang harus dipenuhi selama masa percobaan itu lamanya sama dengan sisa waku pidana penjara yang belum dijalani, ditambah satu tahun. Jika terpidana ada dalam tahanan yang sah, maka waktu itu tidak termasukmasa percobaan. Pelepasan bersyarat diberikan dengan syarat umum bahwa terpidana tidak akan melakukan perbuatan pidana dan perbuatan lain yang tidak baik. Selain itu boleh ditambahkan syarat-syarat khusus mengenai kelakuan terpidana, asal tidak mengurangi kemerdekaan agama dan kemerdekaan politik baginya. ${ }^{43}$ Bimbingan terhadap narapidana yang diberi pembebasan bersyarat yang diberi pembebasan bersyarat dilaksanakan oleh Bapas.

1. Mendapatkan cuti menjelang bebas; ${ }^{44}$

Narapidana yang telah menjalani 2/3 (dua pertiga) masa pidana sekurangkurangnya 9 (sembilan) bulan berkelakuan baik dengan lama cuti sama dengan remisi terakhir yang diterimanya paling lama 6 (enam) bulan. Bagi narapidana cuti menjelang bebas berakhir tepat pada saat bersamaan dengan hari bebas yang sesungguhnya. Izin cuti menjelang bebas diberikan oleh Kanwil Kementerian Hukum dan HAM setempat atas usul dari Kepala Lapas. Pembimbingan narapidana pada waktu cuti menjelang bebas dilakukan oleh petugas Bapas.

m. Mendapatkan hak-hak lain sesuai dengan peraturan perundang-undangan yang berlaku; 45

Hak-hak lain disini adalah hak politik, hak memilih, dan hak keperdataan lainnya. Hak politik bagi narapidana adalah hak untuk menjadi anggota parpol sesuai aspirasinya. Hak memilih adalah hak narapidana untuk menggunakan hak pilihnya dalam pemilu sesuai dengan peraturan peraturan perundang-undangan yang berlaku. Hak keperdataan meliputi surat menyurat dengan keluarga dan sahabat-

\footnotetext{
42 Lihat Pasal 43-48 Peraturan Pemerintah RI Nomor 32 Tahun 1999 Jo PP Nomor 28 Tahun 2006 tentang Syarat dan Tata Cara Pelaksanaan Hak Warga Binaan Pemasyarakatan.

${ }^{43}$ Lihat Pasal 15 dan Pasal 15a ayat (1) dan (2) KUHP.

${ }^{44}$ Lihat Pasal 49-50 Peraturan Pemerintah RI Nomor 32 Tahun 1999 Jo PP Nomor 28 Tahun 2006 tentang Syarat dan Tata Cara Pelaksanaan Hak Warga Binaan Pemasyarakatan.

${ }^{45}$ Lihat Pasal 51-53 Peraturan Pemerintah RI Nomor 32 Tahun 1999 Jo PP Nomor 28 Tahun 2006 tentang Syarat dan Tata Cara Pelaksanaan Hak Warga Binaan Pemasyarakatan.
} 
sahabatnya serta izin keluar Lapas dalam hal-hal luar biasa. Izin keluar Lapas diberikan oleh Kepala Lapas.

Lembaga Pembinaan Khusus Anak (LPKA) merupakan salah satu lembaga pembinaan bagi anak di Pekanbaru. Beberapa Program Pelatihan dan Pembinaan yang dimiliki oleh Lembaga Pembinaan Khusus Anak (LPKA) Pekanbaru adalah sebagai berikut:

a. Pendidikan formal dan non formal Di dalam Lembaga Pembinaan Khusus Anak Pria Pekanbaru dimulai dari tingkat Sekolah Dasar (Paket A) yang bekerjasama dengak sekolah swasta, dan SMU (Paket C) yang merupakan sekolah Swasta. Kepada anak pidana untuk mengasah bakat dan keterampilan agar mereka mempunyai bekal setelah kembali ke dalam masyarakat diberikan pendidikan non formal Pelatihan bengkel, automotif, pelatihan cukur rambut, pertukangan, pertanian dan perkebunan.

b. Pembinaan berupa keagamaan dan konseling Bertujuan perbaikan diri dari anak pidana, ruangan yang terbuka bagi anak yang melakukan tindakan pidana yang memerlukan adanya perhatian lebih banyak sehingga pihak terkait harus mengakomodir hal tersebut. Atau diikuti oleh kegiatan keagamaan yang merupakan pembinaan wajib di Lembaga Pembinaan Khusus Anak Pekanbaru.

c. Mewujudkan ramah anak Sistem Peradilan Pidana Anak (SPPA) seperti yang diamanatkan oleh Undang-Undang Nomor 11 Tahun 2012 yakni lembaga Pemasyarakatan anak (LAPAS Anak) berubah nama Lembaga Pembinaan Khusus An ak (LPKA). Pendekatan terhadap anak lebih menekankan kepada ramah dan layak anak.

Perlakuan sistem terhadap ramah akan anak di aplikasikan seperti pendampingan, pengenalan terhadap diri sendiri dan lingkungannya, program berupa pembinaan, dan pengasuhan terhadap pemasyarakatan hingga mempersiapkan ke reintegrasi sosial anak. pengasuhan pemasyarakatan dapat dilakukan pada saat anak mulai ditempatkan di lembaga Pembinaan Khusus Anak (LPKA). Pembinaan yang diberikan tersebut sudah dirasakan oleh anak-anak di lembaga Pembinaan Khusus Anak (LPKA) Pekanbaru, tetapi masih ada beberapa sarana dan/atau prasarana yang kurang memadai dari lembaga Pembinaan Khusus Anak (LPKA) Pekanbaru.

\section{PENUTUP}

Adapun kesimpulan yang dapat diambil dari hasil penelitian yang telah dilakukan oleh penulis antara lain:

1. Implementasi Kewajiban Pembinaan Terhadap Pidana Anak Di Lembaga Pembinaan Khusus Anak Pekanbaru BerdasarkanUndang-Undang Republik IndonesiaNomor 11 Tahun 2012 Tentang Sistem Peradilan Pidana Anak bahwa pembinaan anak pidana harus memiliki program yang harus dapat memanusiakan anak, mengasuh, membina, membimbing anak pidana. Pembinaan anak pidana harus berorientasi pada nilai kemasyarakatan menurut penulis sesuai dengan penyelenggaraan perlindungan anak. Para pihak yaitu negara, Pembina atau petugas, keluarga, dan masyarakat harus rela berkorban demi terselenggaranya perlindungan dan pemenuhan hak anak pidana. Hal ini merupakan wujud dari nilai Persatuan Indonesia.

2. Akibat Hukum Implementasi Kewajiban Pembinaan Terhadap Pidana Anak Di Lembaga Pembinaan Khusus Anak Pekanbaru BerdasarkanUndang-Undang Republik IndonesiaNomor 11 Tahun 2012 Tentang Sistem Peradilan Pidana Anak bahwa 
perlakuan sistem terhadap ramah akan anak di aplikasikan seperti pendampingan, pengenalan terhadap diri sendiri dan lingkungannya, program berupa pembinaan, dan pengasuhan terhadap pemasyarakatan hingga mempersiapkan ke reintegrasi sosial anak. pengasuhan pemasyarakatan dapat dilakukan pada saat anak mulai ditempatkan di lembaga Pembinaan Khusus Anak (LPKA). Pembinaan yang diberikan tersebut sudah dirasakan oleh anak-anak di lembaga Pembinaan Khusus Anak (LPKA) Pekanbaru, tetapi masih ada beberapa sarana dan/atau prasarana yang kurang

\section{Saran} memadai dari lembaga Pembinaan Khusus Anak (LPKA) Pekanbaru.

Saran yang diberikan oleh penulis setelah melakukan penelitian antara lain: 1) Seharusnya pembinaan anak harus terealisasi karena akan berdampak pada perkembangan anak, (2) Sebaiknya diperlukan pembinaan yang sesuai dengan peraturan perundang-undangan

\section{DAFTAR PUSTAKA}

\section{Peraturan Perundang-Undangan}

Undang-Undang Republik Indonesia No 12 Tahun 1995 Tentang Pemasyarakatan Undang-Undang Nomor 11 Tahun 2012 tentang Sistem Peradilan Pidana Anak

\section{Buku}

Barda Nawawi dan Muladi, 1992, Bunga Rampai Hukum Pidana, Bandung: Alumni.

Djisman Samosir, 1992. Fungsi Pidana Penjara dalam Sistem Pemidanaan di Indonesia, Bandung: Bina Cipta

Gatot Supramono, 2007. Hukum Acara Pengadilan Anak, Jakarta: Djambatan Harsono HS, 1995. Sistem Baru Pembinaan Narapidana, Jakarta: Djambatan John Braithwaite, 2002. Restorative Justice \& Responsive Regulation, New York, Oxford University Press, Inc,

Muladi, H. 2002. ak Asasi Manusia, Politik Dan Sistem Peradilan Pidana, Semarang: Badan Penerbit Universitas Diponegoro

M. Nasir Djamil, 2013. Anak Bukan Untuk Di Hukum, Jakarta: Sinar Grafika

Soerjono Soekanto, Sri Mamudji, 2003. Penelitian Hukum Normatif, Suatu Tinjauan Singkat, Jakarta: PT Raja Grafindo

Soejono Dirdjosisworo, 1985. Sosio Kriminologi: Ilmu-ilmu Sosial dalam Studi Kejahatan, Bandung: Sinar Baru

Yuyun Nurulaen, 2012. Lembaga Pemasyarakatan Masalah \& Solusi, Bandung: Marja Kartini Kartono, 1992. Patologi Sosial, Jakarta: Rajawali Pers

\section{Karya Ilmiah}

Achmad Surya, "Kebijakan Pemberian Remisi Kepada Narapidana Tindak Pidana Korupsi Di Lembaga Pemasyarakatan Kelas IIB Sleman", Tesis Tidak Diterbitkan, Program PascaSarjana, (Yogyakarta: Universitas Gadjah Mada, 2012)

Afrizal, Dedy. "E-Government Service Review In Dumai City Indonesia." Jurnal Niara 13.1 (2020): 260-267.

Didik Setiawan, "Syarat Dan Tata Cara Pemberian Hak-Hak Hukum Bagi Warga Binaan Pemasyarakatan Di Rumah Tahanan Negara Yogyakarta", Skripsi tidak diterbitkan, Fakultas Hukum, (Yogyakarta: Universitas Widya Mataram Yogyakarta, 2011) 
Etti Kusumawati, "Pelaksanaan Pembinaan Narapidana Dan Pembebasan Bersyarat Di Rumah Tahanan Negara (Studi Di Rumah Tahanan Negara Bantul)", Skripsi Tidak Diterbitkan, (Yogyakarta: Universitas Widya Mataram, 2012)

Nani Wita Sembiring, "Efektivitas Pembinaan Narapidana Anak Oleh Lembaga Pemasyarakatan Anak Klas II-A Tanjung Gusta Medan", (Sumatra Utara: Disertai Program Ilmu Kesejahteraan Sosial Universitas, 2009) 
